\title{
Gene array screening for identification of drugs with low levels of adverse side effects
}

\author{
Hermann M. Bolt • Rosemarie Marchan • \\ Jan G. Hengstler
}

Published online: 14 March 2010

(C) Springer-Verlag 2010

One of the success stories of modern toxicology is the identification of gene expression patterns that are associated with specific toxic mechanisms (Ellinger-Ziegelbauer et al. 2008; Sano et al. 2009; Dika Nguea et al. 2008). A wellknown example is the classification algorithm differentiating between genotoxic and non-genotoxic liver carcinogens as opposed to non-carcinogens (Ellinger-Ziegelbauer et al. 2004, 2005, 2008). However, many more compounds or classes of compounds have been shown to be associated with specific gene expression patterns (Tsukue et al. 2009; Schug et al. 2008; Glahn et al. 2008; Hewitt et al. 2007). In this issue of the Archives of Toxicology, Jeffrey F. Waring et al. from Abbott Laboratories present another example of high practical relevance (Waring et al. 2010). In recent years, protease inhibitors have contributed to the reduction of the morbidity and mortality caused by AIDS. These protease inhibitors block cleavage of the gag and gag-pol protein precursors that are required for HIV virus maturation. However, these drugs are associated with adverse side effects. For example, results from clinical studies show an increase in cholesterol and triglyceride levels. Therefore, Waring and colleagues have administered protease inhibitors, which either cause lipid elevations or are relatively lipid neutral. Analyzing gene expression patterns in the liver of exposed rats, they identified increased expression of genes encoding proteasomal subunits specifically in the rats exposed to protease inhibitors known to cause lipid elevations. Based on this observation, the authors specifically screened for protease inhibitors that do not induce the

H. M. Bolt $(\bowtie) \cdot$ R. Marchan · J. G. Hengstler Leibniz Research Centre for Working Environment and Human Factors (IfADo), Leibniz Institut für Arbeitsforschung an der TU Dortmund, Ardeystrasse 67, 44139 Dortmund, Germany e-mail: bolt@ifado.de proteasomal genes. Their efforts led to the identification of a novel protease inhibitor, which did not upregulate proteasomal marker genes and, therefore, may represent a "lipid neutral" compound. It will be very interesting to see whether this prediction can be confirmed in clinical studies.

\section{References}

Dika Nguea H, de Reydellet A, Lehuédé P, De Meringo A, Le Faou A, Marcocci L, Rihn BH (2008) Gene expression profile in monocyte during in vitro mineral fiber degradation. Arch Toxicol 82:355-362

Ellinger-Ziegelbauer H, Stuart B, Wahle B, Bomann W, Ahr HJ (2004) Characteristic expression profiles induced by genotoxic carcinogens in rat liver. Toxicol Sci 77:19-34

Ellinger-Ziegelbauer H, Stuart B, Wahle B, Bomann W, Ahr HJ (2005) Comparison of the expression profiles induced by genotoxic and nongenotoxic carcinogens in rat liver. Mutat Res 575:61-84

Ellinger-Ziegelbauer H, Gmuender H, Bandenburg A, Ahr HJ (2008) Prediction of a carcinogenic potential of rat hepatocarcinogens using toxicogenomics analysis of short-term in vivo studies. Mutat Res 637:23-39

Glahn F, Schmidt-Heck W, Zellmer S, Guthke R, Wiese J, Golka K, Hergenröder R, Degen GH, Lehmann T, Hermes M, Schormann W, Brulport M, Bauer A, Bedawy E, Gebhardt R, Hengstler JG, Foth H (2008) Cadmium, cobalt and lead cause stress response, cell cycle deregulation and increased steroid as well as xenobiotic metabolism in primary normal human bronchial epithelial cells which is coordinated by at least nine transcription factors. Arch Toxicol 82:513-524

Hewitt NJ, Lechón MJ, Houston JB, Hallifax D, Brown HS, Maurel P, Kenna JG, Gustavsson L, Lohmann C, Skonberg C, Guillouzo A, Tuschl G, Li AP, LeCluyse E, Groothuis GM, Hengstler JG (2007) Primary hepatocytes: current understanding of the regulation of metabolic enzymes and transporter proteins, and pharmaceutical practice for the use of hepatocytes in metabolism, enzyme induction, transporter, clearance, and hepatotoxicity studies. Drug Metab Rev 39:159-234

Sano Y, Nakashima H, Yoshioka N, Etho N, Nomiyama T, Nishiwaki Y, Takebayashi T, Oame K (2009) Trichloroethylene liver toxicity 
in mouse and rat: microarray analysis reveals species differences in gene expression. Arch Toxicol 83:835-849

Schug M, Heise T, Bauer A, Storm D, Blaszkewicz M, Bedawy E, Brulport M, Geppert B, Hermes M, Föllmann W, Rapp K, Maccoux L, Schormann W, Appel KE, Oberemm A, Gundert-Remy U, Hengstler JG (2008) Primary rat hepatocytes as in vitro system for gene expression studies: comparison of sandwich, Matrigel and 2D cultures. Arch Toxicol 82:923-931
Tsukue N, Watanabe M, Kumamoto T, Takano H, Takeda K (2009) Perinatal exposure to diesel exhaust affects gene expression in mouse cerebrum. Arch Toxicol 83:985-1000

Waring JF, Ciurlionis R, Marsh K, Klein LL, Degoey DA, Randolph JT, Spear B, Kempf DJ (2010) Identification of proteasome gene regulation in a rat model for HIV protease inhibitor-induced hyperlipidemia. Arch Toxicol [Epub ahead of print] (this issue) 